\title{
A trajectory analysis of atmospheric transport of black carbon aerosols to Canadian high Arctic in winter and spring (1990-2005)
}

\author{
L. Huang ${ }^{1}$, S. L. Gong ${ }^{2}$, S. Sharma ${ }^{3}$, D. Lavoué ${ }^{2}$, and C. Q. Jia ${ }^{1}$ \\ ${ }^{1}$ Department of Chemical Engineering and Applied Chemistry, University of Toronto, 200 College Street, Toronto, \\ ON M5S 3E5 Canada \\ ${ }^{2}$ Air Quality Research Division, Environment Canada, Toronto, ON M3H 5T4 Canada \\ ${ }^{3}$ Climate Research Division, Environment Canada, Toronto, ON M3H 5T4 Canada
}

Received: 22 October 2009 - Published in Atmos. Chem. Phys. Discuss.: 1 February 2010

Revised: 12 May 2010 - Accepted: 17 May 2010 - Published: 4 June 2010

\begin{abstract}
Black carbon (BC) particles accumulated in the Arctic troposphere and deposited on snow have been calculated to have significant effects on radiative forcing of the Arctic regional climate. Applying cluster analysis technique on 10-day backward trajectories, seven distinct transport pathways (or clusters) affecting Alert $\left(82.5^{\circ} \mathrm{N}, 62.5^{\circ} \mathrm{W}\right)$, Nunavut in Canada are identified in this work. Transport frequency associated with each pathway is obtained as the fraction of trajectories in that cluster. Based on atmospheric transport frequency and $\mathrm{BC}$ surface flux from surrounding regions (i.e. North America, Europe, and former USSR), a linear regression model is constructed to investigate the interannual variations of BC observed at Alert in January and April, representative of winter and spring respectively, between 1990 and 2005. Strong correlations are found between $\mathrm{BC}$ concentrations predicted with the regression model and measurements at Alert for both seasons $\left(R^{2}\right.$ equals 0.77 and 0.81 for winter and spring, respectively). Results imply that atmospheric transport and $\mathrm{BC}$ emission are the major contributors to the inter-annual variations in $\mathrm{BC}$ concentrations observed at Alert in the cold seasons for the 16-year period. Other factors, such as deposition, could also contribute to the variability in $\mathrm{BC}$ concentrations but were not considered in this analysis. Based on the regression model the relative contributions of regional $\mathrm{BC}$ emissions affecting Alert are attributed to the Eurasian sector, composed of the European Union and the former USSR, and the North American sector. Considering both seasons, the model suggests that for-
\end{abstract}

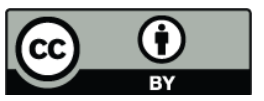

Correspondence to: S. L. Gong (sunling.gong@ec.gc.ca) mer USSR is the major contributor to the near-surface BC levels at the Canadian high Arctic site with an average contribution of about $67 \%$ during the 16-year period, followed by European Union (18\%) and North America (15\%). In winter, the atmospheric transport of $\mathrm{BC}$ aerosols from Eurasia is found to be even more predominant with a multi-year average of $94 \%$. The model estimates smaller contribution from the Eurasian sector in spring (70\%) than that in winter. It is also found that the inter-annual variation in Eurasian contributions depends mainly on the reduction of emissions, while the changes in both emission and atmospheric transport contributed to the inter-annual variation of North American contributions.

\section{Introduction}

Black carbon (BC) particles accumulated in the Arctic troposphere and deposited on snow have been calculated to have significant effects on radiative forcing of the Arctic regional and the global climate (Flanner et al., 2007; Kristjansson et al., 2005; Jacobson, 2001; Hansen and Nazarenko, 2004). Absorbing both the direct and the reflected solar radiation, $\mathrm{BC}$ in the atmosphere was suggested to be the second strongest contributor to current global warming, after carbon dioxide (Ramanathan and Carmichael, 2008; Chung et al., 2005). Once deposited on snow and sea ice, BC changes the surface albedo and contributes to melting of Arctic sea ice (Koch and Hansen, 2005; Jacobson, 2004; Flanner et al., 2007; Kim et al., 2005; Clarke and Noone, 1985). BC particles (along with sulphate and organic carbon) intensively accumulate in the Arctic troposphere during

Published by Copernicus Publications on behalf of the European Geosciences Union. 
the winter and early spring, as a result of the Arctic haze phenomenon (Barrie, 1986; Law and Stohl, 2007; Quinn et al., 2007; Shaw, 1995). The anthropogenic emissions from Europe and former USSR were recently identified to be the major sources of the observed Arctic haze (Stohl, 2006; Quinn et al., 2007; Shindell et al., 2008). However, locations within the Arctic might be impacted differently by source regions. Sharma et al. (2006), for example, showed that Alert $\left(82.5^{\circ} \mathrm{N}, 62.5^{\circ} \mathrm{W}\right)$, Nunavut was about two times more frequently affected by the atmospheric transport of air mass from North America than Point Barrow $\left(71^{\circ} \mathrm{N}, 156.6^{\circ} \mathrm{W}\right)$, Alaska from 1989 to 2003. Worthy et al. (1994) showed that rapid air mass transport from western Russia in winter was responsible for the highest concentrations of $\mathrm{BC}$ measured at Alert.

Based on 13-year continuous observations at Alert, Nunavut since 1989, a broad peak in BC concentration is observed from January to April (Sharma et al., 2006), corresponding to the haze season. For the haze season (January to April), a marked monotonic decreasing trend of BC concentration at Alert during the 1990s, followed by signs of an increase in the early 2000 s, was revealed using a geometric time variation model (Sharma et al., 2004, 2006). The impact of emission variation on the observed BC concentrations was highlighted in their study. For instance, the decreasing trend in $\mathrm{BC}$ concentrations at Alert was associated with the reduction of BC emissions, particularly from the former USSR. Additionally, the important influence of atmospheric transport variability on the inter-annual changes of air pollution levels in the Arctic troposphere was also revealed recently, particularly the effect of North Atlantic Oscillation (NAO) (Eckhardt et al., 2003). However, studies emphasizing the simultaneous effects of varying atmospheric transport and BC emissions are still limited. More recently, the inter-annual variation of $\mathrm{BC}$ was correlated with two atmospheric transport indices derived from the $700 \mathrm{hPa}$ geopotential heights and regional BC emissions, but only 36 and $54 \%$ of the variations can be explained for January and April data (Gong et al., 2010).

In this paper, an attempt is made to investigate the effect of year-to-year changes in both emission and atmospheric transport on the observed inter-annual variation of $\mathrm{BC}$ at Alert from 1990 through 2005, and to further quantify the contributions of $\mathrm{BC}$ emissions from Eurasia and North America based on trajectory analysis technique. The annual BC emissions used in this study are based on the BC inventory prepared by Sharma et al. $(2004,2009)$. To better isolate the effect of atmospheric transport in the cold seasons, 10-day backward trajectories in January and April between 1990 and 2005 are used in this study. The use of January and April data instead of DJF (for winter) and MAM (for spring) is to minimize the seasonal transformation of atmospheric transport patterns in the whole seasons of interest, and to emphasize the inter-annual variation in atmospheric transport. January and April were considered representative of winter and spring, respectively in characterizing the atmospheric circulation affecting the Arctic (Serreze and Barry, 2005). Applying the cluster analysis technique, the transport pathways affecting Alert are identified for both seasons. Based on the obtained transport frequency from cluster analysis and the estimated BC surface flux from surrounding regions, a linear regression model is constructed to reconstruct the yearto-year changes in $\mathrm{BC}$ surface concentrations in winter and spring.

\section{Data and methods}

\subsection{Equivalent black carbon data}

Continuous hourly measurements of aerosol light absorption at Alert have been conducted since 1989. The attenuation of light transmitted through particles collected on a quartz fiber filter was measured using a commercial aethalometer, along with the attenuation of a blank filter. Then the hourly $\mathrm{BC}$ concentrations were calculated based on the difference in attenuation, the filter area, the sample flow rate, and a specific attenuation coefficient $\left(19 \mathrm{~m}^{2} / \mathrm{g}\right)$. The later is determined based upon calibrations during instrument development and theoretical calculations. More detailed description of the method and the determination of the specific attenuation coefficient were documented by Sharma et al. (2004).

\subsection{Trajectory data and transport frequency}

Ten-day backward trajectories arriving at $500 \mathrm{~m}$ above ground level (or a.g.l.) at Alert were initialized 12 times daily (i.e., 00:00, 02:00, 04:00 ... and 22:00 coordinated universal time) for January and April between 1990 and 2005 using the HYSPLIT model (HYbrid Single-Particle Lagrangian Integrated Trajectory, version 4) (Lin et al., 2001). Three-dimensional wind fields from NCEP/NCAR global reanalysis data (Kalnay et al., 1996) were used to drive HYSPLIT, which are available every $6 \mathrm{~h}$ on a 2.5 degree latitude-longitude global grid with 18 vertical levels. The arrival elevation of $500 \mathrm{ma}$ a.g.l. locates within the wintertime Arctic inversion layer so that it is representative of the air sampled at Alert. Worthy et al. (1994), for instance, compared trajectories arriving 1000, 925, 850, and $700 \mathrm{hPa}$ above Alert and suggested that the $925 \mathrm{hPa}$ level (about $540 \mathrm{~m}$ a.g.l.) was the most representative arriving height. Ten-day backward trajectories are used in this study since trajectories of a shorter duration are usually not long enough to indicate possible distant source regions affecting the Arctic (Harris and Kahl, 1990). Although longer trajectories are generally subject to higher uncertainty, progressive advances in generating meteorological fields, computing trajectories, and especially, the implementation of cluster analysis technique on a large set of trajectories in this study may, to some extent, reduce the effects of individual errors 
(Kahl, 1990; Harris and Kahl, 1994). The clustering algorithm described by Dorling et al. (1992) was modified (refer to Supplementary Information: Modified Dorling's algorithm, see http://www.atmos-chem-phys.net/10/5065/2010/ acp-10-5065-2010-supplement.pdf) to effectively group trajectories. Each group of trajectories represents a distinct transport pathway bringing air masses into Alert. In this study, the transport frequency (dimensionless) associated with a pathway is defined as the percentage of trajectories in that group.

\subsection{Surface flux of BC}

Analyzing the inter-annual variation in the Arctic $\mathrm{BC}$ required building annual $\mathrm{BC}$ emission inventories by country from 1990 through 2005. Wintertime black carbon in the northern mid-latitudes is predominantly emitted from incomplete fossil fuel combustion. Although neglected by this study, BC emissions from biofuel combustion and open biomass burning are expected to have only limited effects on the surface measurements at Alert in January and April. Based on the BC emission inventory for 1996 (Bond et al., 2004), the overall emission of BC from fossil fuel combustion is about 9 (4) times higher than that from biofuel for the region north of $50^{\circ} \mathrm{N}\left(30^{\circ} \mathrm{N}\right)$. And the major biofuel emissions are from South and East Asia. BC emissions from open biomass burning do not occur during winter (or January) and have significant impacts on $\mathrm{BC}$ concentrations mainly in the free troposphere rather than the boundary layer in the Arctic troposphere (Warneke et al., 2010).

The regional $\mathrm{BC}$ emissions used in this study were calculated from consumption and transaction amounts of 23 different fuel types compiled by the United Nations (United Nations, 2007). The method implemented in this study to compute emissions was initially developed by Cooke et al. (1999) for 1970-1989. The period of the emission inventory was extended a first time to $1990-1998$ by Sharma et al. (2004) and through 2005 by Sharma et al. (2009). Global BC emissions were also developed by Bond et al. (2004, 2007), but only emissions every 5 years until 2000 are available to the public on their web site (http://www.hiwater.org). Comparing $\mathrm{BC}$ emissions used in this study with Bond's estimations for the year 2000, we determined global emissions of $7200 \mathrm{Gg}$, while they totalized $4537 \mathrm{Gg}$, i.e. $37 \%$ less. For 1990 , the difference calculated is similar, which is well within their estimated emission uncertainty (i.e. a factor of 2) (Bond et al., 2004, 2007).

Based on the work of Stohl (2006), North America (50$\left.180^{\circ} \mathrm{W}\right)$, European Union $\left(15^{\circ} \mathrm{W}-15^{\circ} \mathrm{E}\right)$ and the former USSR $\left(15-180^{\circ} \mathrm{E}\right)$ are the major BC source regions affecting the Arctic. The areas of the above regions cover the whole land area of these regions, which are obtained based on the Gridded Population of the World, version 3 (GPWv3, available at http://sedac.ciesin.columbia.edu/gpw). The BC surface fluxes from these regions for 1990-2005 are calculated

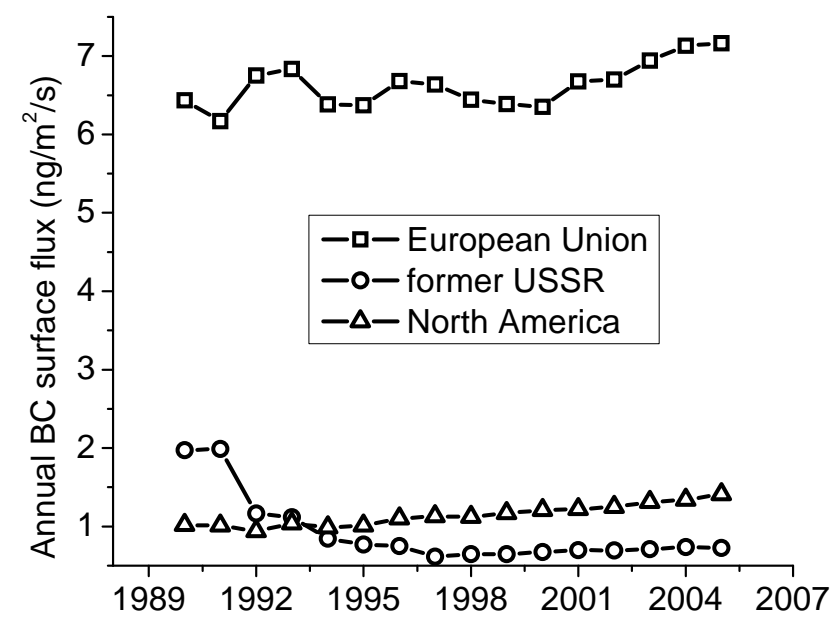

Fig. 1. Annual average BC surface flux $\left(\mathrm{ng} / \mathrm{m}^{2} / \mathrm{s}\right)$ from European Union, the former USSR, and North America: 1990-2005.

by dividing annual regional emissions by regional surface area and time, as shown in Fig. 1. On average of the 16year period, the surface flux of European Union is about 6 (7) times higher than that of North America (former USSR). BC surface flux in the former USSR decreased by more than $50 \%$ of its 1990 level during the first half of the 1990s, and since then has remained fairly stable with signs of a progressive increase. The North American sector has increased steadily during the 16-year period.

\subsection{Simple linear regression model}

A mass balance approach is used to establish the linkage among the surface flux of $\mathrm{BC}$ anthropogenic emissions, the frequency of atmospheric transport, and the measured $\mathrm{BC}$ surface concentrations, which has the following formula

$[\mathrm{BC}]_{\mathrm{Jan} / \mathrm{Apr}, j}=\sum_{i=1}^{n}\left(f_{i, j} \cdot C_{i, j}\right)$

where $i=1,2, \ldots n$ is an arbitrary index for atmospheric transport pathways affecting Alert and $j=1990,1991, \ldots, 2005$ represents year from 1990 through 2005. For the year of $j$, the left-hand side of the above equation represents the monthly average $\mathrm{BC}$ concentration observed in January or April (in $\mathrm{ng} / \mathrm{m}^{3}$ ), $f_{i, j}$ (in percentage) is the transport frequency of the $i$-th pathway, and $C_{i, j}\left(\right.$ in $\left.\mathrm{ng} / \mathrm{m}^{3}\right)$ is defined as the BC concentration that would be measured if only the $i$-th transport pathway had affected the receptor.

It is then assumed in this study that the characteristic BC concentration of a transport pathway is linearly proportional to the surface flux of BC emission at source region identified by trajectory cluster analysis. The mass balance model takes the following form,

$[\mathrm{BC}]_{\mathrm{Jan} / \mathrm{Apr}, j}=\sum_{i=1}^{n}\left(f_{i, j} \cdot b_{i} \cdot E_{i, j}\right)$ 
where $E_{i, j}$ (in $\mathrm{ng} / \mathrm{m}^{2} / \mathrm{s}$ ) represents the surface flux of $\mathrm{BC}$ emission from source region $i$ in the year of $j$ and $b_{i}$ (in s/m) is a cluster specific proportional constant. The final form of the mass balance model shows a linear dependence of monthly average $\mathrm{BC}$ concentration ([BC]) on transport frequency $(f)$ and surface flux $(E)$, which are obtained following the methodologies described in Sects. 2.1-2.3. It is a simple linear regression model with the independent variable or predictor $\sum_{i=1}^{n}\left(f_{i, j} \cdot E_{i, j}\right)$ and the slope $b_{i}$. It is physically meaningful to have a zero intercept in this model, which implies that $\mathrm{BC}$ emissions other than those considered in this study have negligible impact on the near-surface $\mathrm{BC}$ concentration observed at Alert. It was previously shown using a particle dispersion model that the $\mathrm{BC}$ source contribution to the entire Arctic troposphere from south Asia is only $10 \%$ of the European contribution (Stohl, 2006). Given BC concentrations, transport frequencies, and surface fluxes, the slope $\left(b_{i}\right)$ is estimated using the least squares method. The purpose of introducing the $\mathrm{b}$ factors is to relate the available surface emission inventories to the observed concentrations at the receptor when atmospheric transport from source regions takes place. The $b$ factors are assumed to be the ratio of the concentration in the air to the surface emission flux. So it is region and transport pathway specific, which has the unit of $\mathrm{s} / \mathrm{m}$. In principle, atmospheric processes that modify $\mathrm{BC}$ concentration during the transport of $\mathrm{BC}$ from source regions to the receptor contribute to the $\mathrm{b}$ values. Presumably, the $\mathrm{b}$ factors would mainly depend on mixing heights $(\mathrm{m})$ in the source regions and aerosol removal processes $(1 / \mathrm{s})$. For example, greater mixing height in a source region would result in more dilution of the initial BC concentration in the air, and thus reduces the $b$ value associated with that specific source region. At the same time, if an atmospheric transport pathway is associated with relatively fast aerosol removal processes (possibly due to long distance of transport, fast transformation from hydrophobic to hydrophilic particles, frequent precipitation events, and so on), one would expect a small b value specifically for this pathway.

\section{Results and discussion}

\subsection{Transport pathways affecting Alert}

Ten-day backward trajectories for January and April from 1990 through 2005 are classified into 7 distinct groups by implementing the modified clustering algorithm. The clustermean trajectories, which indicate the average atmospheric flow patterns, are shown in Fig. 2. The identified 7 transport pathways are distinct in wind direction and speed. First of all, there are several specific characteristics that can be found for the air masses arriving at Alert in January. In terms of transport frequency, clusters 1,2 , and 6 are among the most frequent transport pathways, which in total account for $55 \%$ of
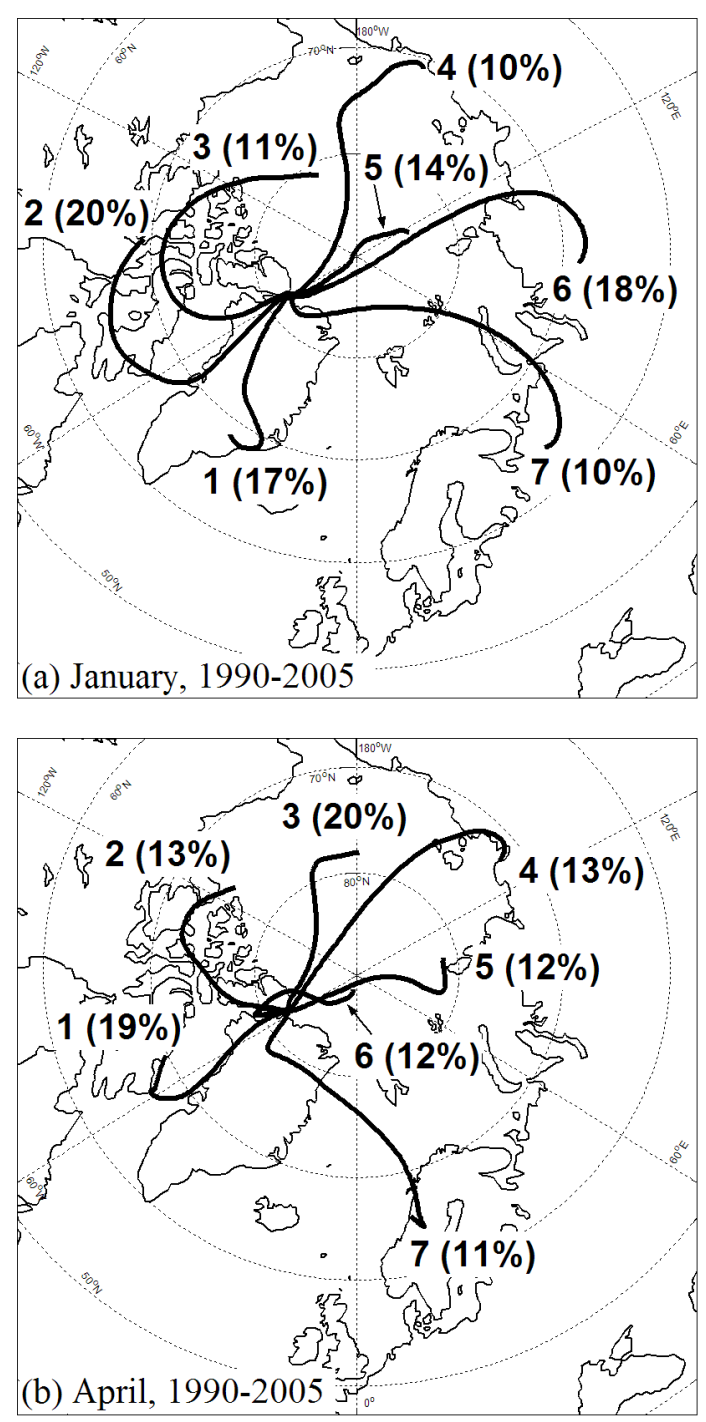

Fig. 2. Transport pathways affecting Alert, Nunavut in January (a) and April (b) from 1990 through 2005 identified by cluster analysis. Each plotted pathway shows the average of 10-day back trajectories generated by the HYSPLIT model. The number outside the brackets serves only as an identification of each cluster; the one inside the brackets gives the frequency of occurrence of the underlining transport pathway.

atmospheric transport in winter. In terms of wind direction, it was found that southerly (clusters 1,2, and 3) and northerly (clusters 4, 5, 6, and 7) flows dominate the wintertime atmospheric transport. For the period of interest, northerly winds constitute slightly over $50 \%$ of the total flows and the rest is from southerly transport. Among southerly transport routes, clusters 2 and 3 indicate transport of air masses from south and southwest to the receptor Alert. The cluster-member plot for cluster 2 (refer to Supplementary Information: cluster-member plots, see http://www.atmos-chem-phys.net/ 10/5065/2010/acp-10-5065-2010-supplement.pdf) indicates 
that most of the trajectories in this group originally started from Canada or Alaska, moved first towards southeast of Canada, and turned north between Baffin Island and Greenland due to the effect of geographic barrier. Cluster 3 (about $11 \%$ ) is composed of trajectories with a strong westerly wind component. The trajectories in this cluster are mostly found to originate between Eastern Siberia and the Beaufort Sea, although few are found from Bering Sea. Cluster 1 (17\%), however, contains trajectories passing through the European Arctic region. Trajectories in this cluster initiated from the North Atlantic Ocean and Europe.

Among the northerly transport pathways in Fig. 2a, cluster 5 is characterized as a relatively slow northerly moving group, which is found about $14 \%$ of the time in January. Trajectories grouped into this cluster initiated from the northern high latitudes of the former USSR, but they are found cycling around the Alert site. During the 10-day transport to Alert, trajectories in this group spent considerable amount of time traveling above the sea ice covering the Arctic Ocean. In January, several fully developed long-range transport pathways bringing air masses from Eurasia into Alert are found with considerable frequency of occurrence. This type of pathways includes clusters 4, 6, and 7 in Fig. 2a. Cluster 7 (about 10\%) represents the transport of mid-latitude continental air masses from Eastern Europe. A number of trajectories in this cluster extend deeply into the mid-latitudes as far south as $45^{\circ} \mathrm{N}$. Many of them traveled eastwards for the first one or two days before entering the Arctic region. In cluster 6, trajectories started within a wide area of Siberia and extended also deeply into the continent (about $50^{\circ} \mathrm{N}$ in latitude). Such long range transport is found during the winter $18 \%$ of the time. Cluster $4(10 \%)$ represents atmospheric transport mainly from Eastern Siberia, but it contains few trajectories originated from Bering Sea and Alaska.

Compared to the atmospheric transport patterns in January, the cyclonic feature is much weaker and the length of trajectories is shorter in April, due to shifted and weakened surface pressure systems: the Siberian High, the Icelandic Low, and the Aleutian Low (Serreze and Barry, 2005). Thus, long-range transport from the mid-latitudes is less frequent in spring compared to winter. The monthly average trajectory length in April is about 38\% shorter than January between 1990 and 2005. In Fig. 2b, clusters 1 and 2 represent transport originated from the central and the northwestern North America, respectively. Cluster 3 is composed of trajectories from Eastern Siberia, and clusters 4 and 5 point to the central northern Siberia. Transport of air mass from Europe in April is only found in cluster 7 .

According to the direction of each identified transport pathway, the linkage between the source of emission and the receptor is established. Tables 1 and 2 present the yearto-year changes in atmospheric transport frequency between 1990 and 2005 for winter and spring, respectively. In the North American sector, the frequency of atmospheric transport increases by about $10 \%$ from winter to spring. In the
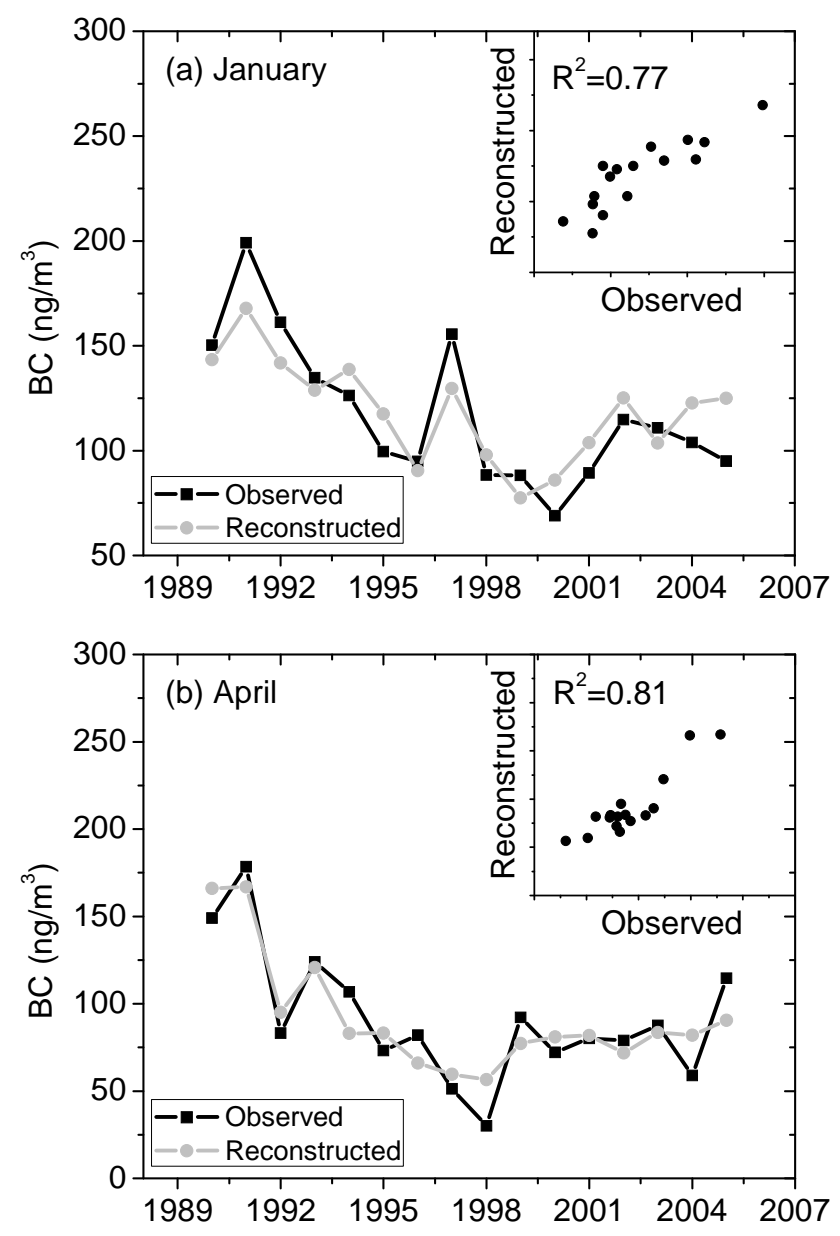

Fig. 3. Time-series of the model reconstructed and the observed monthly average BC concentrations in January (a) and April (b), 1990-2005. The $R^{2}$ shown in both plots are the squares of the Pearson's correlation coefficients between the reconstructed and observed $\mathrm{BC}$ concentrations rather than those for linear regressions.

former USSR sector, transport from the western and the central USSR increases by $6 \%$ in spring compared to the winter pattern. Compared to that in winter, the frequency of transport from Europe in spring also decreases significantly by $15 \%$.

\subsection{Inter-annual variations of $\mathrm{BC}$ at Alert explained by the model}

The transport frequency obtained in the previous section is then used here as $f$ values in Eq. (2). Given monthly average $\mathrm{BC}$ concentrations ([BC]), transport frequency $(f)$, and surface BC flux $(E)$, the linear regression model (Eq. 2) is solved using the least squares method, and the region specific $b$ factors, as well as the individual p-values, are given in Table 3 for both seasons. The regressions are significant at $95 \%$ confidence level for both seasons. The timeseries and the correlation between model reconstructed and 
Table 1. Inter-annual variation of transport frequency (trajectory number of each sector divided by the total number of trajectories, in percentage) affecting Alert in January, 1990-2005.

\begin{tabular}{lc|cccc|cc}
\hline & $\begin{array}{c}\text { North America } \\
\text { Cluster 2 }\end{array}$ & Cluster 3 & Cluster 4 & Cluster 5 & Cluster 6 & European Union \\
Cluster 1 & Cluster 7 \\
\hline 1990 & $25 \%$ & $3 \%$ & $0 \%$ & $0 \%$ & $17 \%$ & $33 \%$ & $21 \%$ \\
1991 & $55 \%$ & $0 \%$ & $7 \%$ & $10 \%$ & $17 \%$ & $9 \%$ & $2 \%$ \\
1992 & $30 \%$ & $4 \%$ & $10 \%$ & $32 \%$ & $6 \%$ & $11 \%$ & $8 \%$ \\
1993 & $14 \%$ & $42 \%$ & $3 \%$ & $0 \%$ & $27 \%$ & $14 \%$ & $0 \%$ \\
1994 & $5 \%$ & $2 \%$ & $19 \%$ & $19 \%$ & $33 \%$ & $11 \%$ & $12 \%$ \\
1995 & $12 \%$ & $4 \%$ & $6 \%$ & $37 \%$ & $25 \%$ & $13 \%$ & $3 \%$ \\
1996 & $31 \%$ & $26 \%$ & $11 \%$ & $4 \%$ & $9 \%$ & $18 \%$ & $0 \%$ \\
1997 & $11 \%$ & $6 \%$ & $9 \%$ & $10 \%$ & $21 \%$ & $1 \%$ & $43 \%$ \\
1998 & $19 \%$ & $5 \%$ & $18 \%$ & $7 \%$ & $11 \%$ & $31 \%$ & $10 \%$ \\
1999 & $1 \%$ & $15 \%$ & $2 \%$ & $8 \%$ & $0 \%$ & $70 \%$ & $4 \%$ \\
2000 & $43 \%$ & $29 \%$ & $6 \%$ & $10 \%$ & $7 \%$ & $6 \%$ & $0 \%$ \\
2001 & $26 \%$ & $13 \%$ & $0 \%$ & $14 \%$ & $20 \%$ & $15 \%$ & $11 \%$ \\
2002 & $2 \%$ & $3 \%$ & $16 \%$ & $14 \%$ & $39 \%$ & $10 \%$ & $15 \%$ \\
2003 & $15 \%$ & $21 \%$ & $18 \%$ & $19 \%$ & $7 \%$ & $15 \%$ & $3 \%$ \\
2004 & $23 \%$ & $5 \%$ & $28 \%$ & $4 \%$ & $34 \%$ & $2 \%$ & $2 \%$ \\
2005 & $18 \%$ & $6 \%$ & $1 \%$ & $21 \%$ & $9 \%$ & $19 \%$ & $27 \%$ \\
Average & $21 \%$ & & & $52 \%$ & & & $27 \%$ \\
\hline
\end{tabular}

Table 2. Same as Table 1, but for April, 1990-2005.

\begin{tabular}{lcc|cccc|c}
\hline & $\begin{array}{c}\text { North America } \\
\text { Cluster 1 }\end{array}$ & Cluster 2 & Cluster 3 & Cluster 4 & Cluster 5 & Cluster 6 & $\begin{array}{c}\text { European Union } \\
\text { Cluster 7 }\end{array}$ \\
\hline 1990 & $15 \%$ & $11 \%$ & $38 \%$ & $13 \%$ & $2 \%$ & $0 \%$ & $22 \%$ \\
1991 & $1 \%$ & $16 \%$ & $26 \%$ & $16 \%$ & $0 \%$ & $41 \%$ & $1 \%$ \\
1992 & $38 \%$ & $0 \%$ & $13 \%$ & $2 \%$ & $20 \%$ & $17 \%$ & $11 \%$ \\
1993 & $2 \%$ & $4 \%$ & $24 \%$ & $40 \%$ & $12 \%$ & $8 \%$ & $9 \%$ \\
1994 & $33 \%$ & $8 \%$ & $21 \%$ & $4 \%$ & $19 \%$ & $5 \%$ & $11 \%$ \\
1995 & $19 \%$ & $7 \%$ & $16 \%$ & $16 \%$ & $27 \%$ & $0 \%$ & $15 \%$ \\
1996 & $19 \%$ & $0 \%$ & $6 \%$ & $0 \%$ & $0 \%$ & $0 \%$ & $74 \%$ \\
1997 & $22 \%$ & $4 \%$ & $8 \%$ & $4 \%$ & $11 \%$ & $38 \%$ & $14 \%$ \\
1998 & $8 \%$ & $17 \%$ & $6 \%$ & $0 \%$ & $9 \%$ & $43 \%$ & $17 \%$ \\
1999 & $11 \%$ & $12 \%$ & $21 \%$ & $8 \%$ & $40 \%$ & $8 \%$ & $0 \%$ \\
2000 & $39 \%$ & $11 \%$ & $29 \%$ & $14 \%$ & $5 \%$ & $2 \%$ & $0 \%$ \\
2001 & $37 \%$ & $4 \%$ & $18 \%$ & $38 \%$ & $1 \%$ & $1 \%$ & $0 \%$ \\
2002 & $0 \%$ & $69 \%$ & $14 \%$ & $10 \%$ & $0 \%$ & $7 \%$ & $0 \%$ \\
2003 & $3 \%$ & $5 \%$ & $52 \%$ & $15 \%$ & $7 \%$ & $17 \%$ & $1 \%$ \\
2004 & $25 \%$ & $11 \%$ & $7 \%$ & $15 \%$ & $22 \%$ & $8 \%$ & $13 \%$ \\
2005 & $36 \%$ & $1 \%$ & $26 \%$ & $12 \%$ & $19 \%$ & $6 \%$ & $0 \%$ \\
Average & & $30 \%$ & & & $58 \%$ & & $12 \%$ \\
\hline
\end{tabular}

Table 3. Values of $b_{i}$ factors for January and April, 1990-2005.

\begin{tabular}{lrrrrrrr}
\hline & $b_{1}$ & $b_{2}$ & $b_{3}$ & $b_{4}$ & $b_{5}$ & $b_{6}$ & $b_{7}$ \\
\hline January & 11.0 & 68.4 & 100.3 & 192.7 & 167.1 & 181.4 & 43.7 \\
p-value & 0.048 & 0.081 & 0.088 & 0.082 & 0.017 & 0.006 & 0.006 \\
April & 65.8 & 54.8 & 137.6 & 113.8 & 129.0 & 62.6 & 9.2 \\
p-value & 0.037 & 0.045 & 0.002 & 0.046 & 0.045 & 0.046 & 0.048 \\
\hline
\end{tabular}


the observed monthly average $\mathrm{BC}$ concentrations are shown in Fig. 3. Strong positive correlations are found between the model reconstructed and the observed $\mathrm{BC}$ at Alert for both seasons. The square of Pearson's correlation coefficient $\left(R^{2}\right)$ indicates the fraction of the inter-annual variations in observations explained by our linear regression model. As shown in Fig. 3, our model is able to explain $77 \%$ of the variation in the observed BC for winter, and over $80 \%$ is explained for spring, which is considerably better than the approach developed by Gong et al. (2010). Given the same BC emission dataset used in both studies, the better correlations obtained in this study are probably due to the implementation of 3-D trajectories followed by cluster analysis to better represent transport pathways affecting Alert rather than the pressure difference on a specific pressure level. It may also be partially due to the introduction of the pathway specific $b$ factors, which implicitly account for the effect of atmospheric $\mathrm{BC}$ removal. Thus, about $80 \%$ of the inter-annual variation of BC concentrations observed at Alert between 1990 and 2005 is reconstructed by considering the year-to-year changes in transport frequency and surface emission flux. The ability of our model to reconstruct BC inter-annual variability implies that atmospheric transport plays an important role in connecting source emissions and the surface $\mathrm{BC}$ observed at the Canadian high Arctic site during the haze season. In such an extreme cold season, favorable meteorological conditions, such as stable stratification, surface temperature inversion, and extreme dryness, suppress mixing, dry deposition, and wet scavenging of $\mathrm{BC}$ in the air and, therefore, enhance the long-range atmospheric transport.

About $20 \%$ of the inter-annual variation in observations cannot be explained by this approach. The uncertainty of this approach is affected by several assumptions made in the current study. First, the atmospheric removal mechanisms are not explicitly included in our approach. By assuming constant $\mathrm{b}$ factors with respect to the identified transport pathways, constant removal efficiencies during transport are implicitly assumed between 1990 and 2005. This assumption may not perfectly hold for years with extreme precipitation events. In January, 1997, for instance, the area averaged precipitation accumulation at the European sector is found the lowest among the period of interest, and it is estimated $33 \%$ lower than the multi-year average based on the Climate Prediction Center (CPC) Merged Analysis of Precipitation (CMAP) dataset (Huffman et al., 1997). Thus, the underestimation (about $25 \mathrm{ng} / \mathrm{m}^{3}$ or $17 \%$ lower than the observation) in January, 1997 may be partly due to the extreme dry conditions, which substantially suppressed the wet scavenging of aerosols. In January, 1995, however, the highest precipitation accumulation at the European sector (33\% higher than the multi-year average) was found, which may partly explain the overestimation (about $18 \mathrm{ng} / \mathrm{m}^{3}$ or $18 \%$ higher than the observation) by our model. Another major source of uncertainty is the assumption that $\mathrm{BC}$ particles are uniformly distributed at the regions of emission. The regional $\mathrm{BC}$ surface

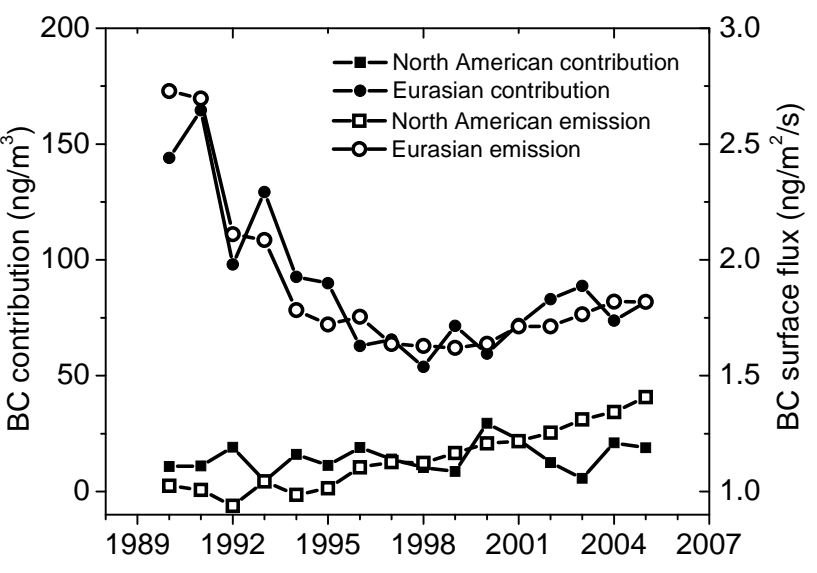

Fig. 4. Model estimated source contributions of BC from the North American and the Eurasian sectors based on the average of January and April from 1990 through 2005. The inter-annual changes in BC surface flux are show by two dashed lines.

flux used in this study does not consider the geographic distribution of $\mathrm{BC}$ emissions within the potential source regions. Uncertainties of this approach may also come from trajectory calculation, emission data, and the implicit treatment of particle dry deposition and air mass mixing during the transport. To reduce all these sources of uncertainties, a study implementing the state-of-the-art aerosol model is on-going.

\subsection{Source contributions to $\mathrm{BC}$ at Alert}

The contributions of $\mathrm{BC}$ transport from Eurasia (former USSR and European Union combined) and North America are estimated based on the average of January and April from 1990 through 2005, as shown in Fig. 4. The annual average BC emission fluxes of North America and Eurasia are also shown for comparison. Comparing the importance of these two regions in affecting Alert, contributions from Eurasia dominate throughout the 16-year period. The model suggests that BC emitted from the former USSR and European Union contributes about $70 \mathrm{ng} / \mathrm{m}^{3}$ (or $67 \%$ ) and $19 \mathrm{ng} / \mathrm{m}^{3}$ (or $18 \%$ ), respectively to the measured $\mathrm{BC}$ particles at Alert to the measured BC mass at Alert, while North America contributes less than $15 \mathrm{ng} / \mathrm{m}^{3}$ (or $15 \%$ ) on 16-year average. Therefore, it is estimated that Eurasia contributes about $90 \mathrm{ng} / \mathrm{m}^{3}$ (or $85 \%$ ) to the measured BC particles at Alert. In January, the effect of the Eurasian emission is found to be even more predominant (94\%) than that in April (70\%), which is due to the enhanced long-range transport in January. The case study conducted by Worth et al. (1994), for example, found that the observed peaks in BC concentration at Alert can be attributed to long-range transport events from the Eurasian sector. The estimated relative importance of the North American and Eurasian BC emissions agree well with recent studies. Based on January-April average, Gong et al. (2010) estimated that the Eurasian contribution varied between $80-90 \%$ 
and the North American contribution was about $10-20 \%$ for the same period of time. The estimates by this study also agree well with a most recent multi-model estimation conducted by Shindell et al. (2008). In their study, the contribution from North America was estimated to be $10 \%$ for the year of 2001, based on the average estimation from 16 models. The Eurasian contribution for 2001 was estimated to be $72 \%$ (90\%) without (with) Asian BC emissions considered.

The model also suggests that the contribution of Eurasia declined significantly in the first 8-10 years after 1990 . However, a slightly increasing trend can be noticed since the late 1990s to 2005 on the Eurasian contribution curve in Fig. 4. The relative importance of atmospheric transport and $\mathrm{BC}$ emission in governing the inter-annual variations of regional contributions to the near-surface $\mathrm{BC}$ level at Alert is also investigated. The Pearson's correlation coefficient between the Eurasian contribution and BC surface flux from that region is found to be 0.93 , which indicates that the interannual change in Eurasian contributions is mainly attributed to regional $\mathrm{BC}$ emission reduction during the 16-year period rather than the changes in atmospheric transport. On the other hand, the correlation for the North American side is very poor $(R=0.23)$. The North American contributions for the same period did not simply depend on regional BC emission, but also on other factors, especially atmospheric transport patterns, as indicated by the good agreement between measured and reconstructed $\mathrm{BC}$ surface concentration.

\section{Conclusions}

Based on the atmospheric transport frequency and the estimated surface flux of $\mathrm{BC}$ emissions from surrounding regions, a linear regression model is constructed to investigate the inter-annual variations of BC observed at Alert in January and April, representative of winter and spring respectively, from 1990 through 2005. The atmospheric transport frequency is obtained by conducting cluster analysis on 10-day backward trajectories arriving at Alert. Annual BC emission from potential source regions (i.e. European Union, former USSR, and North America) used in this study is an extended database initially developed by Cooke et al. (1999). Solving the linear model, strong correlations are found between $\mathrm{BC}$ concentrations predicted with the regression model and measured at Alert for both seasons. The linear model is able to explain $77 \%$ of the inter-annual variation of $\mathrm{BC}$ for winter, and over $80 \%$ is explained for spring. Results imply that atmospheric transport and $\mathrm{BC}$ emission are the major contributors to the inter-annual variations in $\mathrm{BC}$ concentrations observed at Alert in the cold seasons for the 16-year period. The portion of unexplained inter-annual variation (about 20\%) may be due to the limitation of this analysis, such as the lack of an explicit representation of the year-toyear change in deposition and the assumption of a uniform distribution of $\mathrm{BC}$ surface flux within source region.
The relative importance of North American and Eurasian emissions to $\mathrm{BC}$ concentration at Alert is also investigated. Considering both seasons, the model suggests that Eurasia is the major contributor to the near-surface $\mathrm{BC}$ levels at the Canadian high Arctic site with an average contribution of over $85 \%$ during the 16 -year period. In winter, the atmospheric transport of $\mathrm{BC}$ aerosols from Eurasia is found to be even more predominant with a multi-year average of $94 \%$. The model estimates smaller contribution from the Eurasian sector in spring (70\%) than that in winter. Results suggest that atmospheric transport and $\mathrm{BC}$ emission played different roles in governing the inter-annual variations of regional contributions to the near-surface BC level at Alert. It is found that the change in Eurasian contributions depends mainly on the reduction of $\mathrm{BC}$ emissions. On the other hand, the interannual variation of the North American contributions was due to the changes in both emission and atmospheric transport. In agreement with Gong et al. (2010), controlling BC emissions in Eurasia seems to be an effective way to reduce $\mathrm{BC}$ levels in the Arctic lower troposphere in the cold seasons.

Acknowledgements. The authors gratefully acknowledge the NOAA Air Resources Laboratory (ARL) for the provision of the HYSPLIT transport and dispersion model and READY website (http://www.arl.noaa.gov/ready.html) used in this publication.

Edited by: A. Stohl

\section{References}

Barrie, L. A.: Arctic air-pollution - an overview of current knowledge, Atmos. Environ., 20, 643-663, 1986.

Bond, T. C., Streets, D. G., Yarber, K. F., Nelson, S. M., Woo, J. H., and Klimont, Z.: A technology-based global inventory of black and organic carbon emissions from combustion, J. Geophys. Res.-Atmos., 109(43), D14203, doi:10.1029/2003jd003697, 2004.

Bond, T. C., Bhardwaj, E., Dong, R., Jogani, R., Jung, S. K., Roden, C., Streets, D. G., and Trautmann, N. M.: Historical emissions of black and organic carbon aerosol from energy-related combustion, 1850-2000, Global Biogeochem. Cy., 21(16), GB2018, doi:10.1029/2006gb002840, 2007.

Chung, C. E., Ramanathan, V., Kim, D., and Podgorny, I. A.: Global anthropogenic aerosol direct forcing derived from satellite and ground-based observations, J. Geophys. Res.-Atmos., 110(17), D24207, doi:10.1029/2005jd006356, 2005.

Clarke, A. D. and Noone, K. J.: Soot in the Arctic snowpack a cause for perturbations in radiative-transfer, Atmos. Environ., 19, 2045-2053, 1985.

Cooke, W. F., Liousse, C., Cachier, H., and Feichter, J.: Construction of a 1 degrees x 1 degrees fossil fuel emission data set for carbonaceous aerosol and implementation and radiative impact in the ECHAM4 model, J. Geophys. Res.-Atmos., 104, 2213722162, 1999.

Dorling, S. R., Davies, T. D., and Pierce, C. E.: Cluster-analysis a technique for estimating the synoptic meteorological controls 
on air and precipitation chemistry - method and applications, Atmos. Environ. A, 26, 2575-2581, 1992.

Eckhardt, S., Stohl, A., Beirle, S., Spichtinger, N., James, P., Forster, C., Junker, C., Wagner, T., Platt, U., and Jennings, S. G.: The North Atlantic Oscillation controls air pollution transport to the Arctic, Atmos. Chem. Phys., 3, 1769-1778, doi:10.5194/acp3-1769-2003, 2003.

Flanner, M. G., Zender, C. S., Randerson, J. T., and Rasch, P. J.: Present-day climate forcing and response from black carbon in snow, J. Geophys. Res.-Atmos., 112(17), D11202, doi:10.1029/2006jd008003, 2007.

Gong, S. L., Zhao, T. L., Sharma, S., Toom-Sauntry, D., Lavoue, D., Zhang, X. B., Leaitch, W. R., and Barrie, L.: Identification of trends and inter-annual variability of sulphate and black carbon in the Canadian High Arctic: 1981 to 2007, J. Geophys. Res.Atmos., 115, D07305, doi:10.1029/2009JD012943, 2010.

Hansen, J. and Nazarenko, L.: Soot climate forcing via snow and ice albedos, P. Natl. Acad. Sci. USA, 101, 423-428, doi:10.1073/pnas.2237157100, 2004.

Harris, J. M. and Kahl, J. D.: A Descriptive Atmospheric Transport Climatology for the Mauna-Loa-Observatory, Using Clustered Trajectories, J. Geophys. Res.-Atmos., 95, 13651-13667, 1990.

Harris, J. M. and Kahl, J. D. W.: Analysis of 10-Day Isentropic Flow Patterns for Barrow, Alaska - 1985-1992, J. Geophys. Res.-Atmos., 99, 25845-25855, 1994.

Huffman, G. J., Adler, R. F., Arkin, P., Chang, A., Ferraro, R., Gruber, A., Janowiak, J., McNab, A., Rudolf, B., and Schneider, U.: The Global Precipitation Climatology Project (GPCP) Combined Precipitation Dataset, B. Am. Meteorol. Soc., 78, 5-20, 1997.

Jacobson, M. Z.: Strong radiative heating due to the mixing state of black carbon in atmospheric aerosols, Nature, 409, 695-697, 2001.

Jacobson, M. Z.: Climate response of fossil fuel and biofuel soot, accounting for soot's feedback to snow and sea ice albedo and emissivity, J. Geophys. Res.-Atmos., 109(15), D21201, doi:10.1029/2004jd004945, 2004.

Kahl, J. D.: Characteristics of the Low-Level Temperature Inversion Along the Alaskan Arctic Coast, Int. J. Climatol., 10, 537-548, 1990.

Kalnay, E., Kanamitsu, M., Kistler, R., Collins, W., Deaven, D., Gandin, L., Iredell, M., Saha, S., White, G., Woollen, J., Zhu, Y., Chelliah, M., Ebisuzaki, W., Higgins, W., Janowiak, J., Mo, K. C., Ropelewski, C., Wang, J., Leetmaa, A., Reynolds, R., Jenne, R., and Joseph, D.: The NCEP/NCAR 40-year reanalysis project, B. Am. Meteorol. Soc., 77, 437-471, 1996.

Kim, Y., Hatsushika, H., Muskett, R. R., and Yamazaki, K.: Possible effect of boreal wildfire soot on Arctic sea ice and Alaska glaciers, Atmos. Environ., 39, 3513-3520, doi:10.1016/j.atmosenv.2005.02.050, 2005.

Koch, D. and Hansen, J.: Distant origins of Arctic black carbon: A Goddard Institute for Space Studies ModelE experiment, J. Geophys. Res.-Atmos., 110(14), D04204, doi:10.1029/2004jd005296, 2005.

Kristjansson, J. E., Iversen, T., Kirkevag, A., Seland, O., and Debernard, J.: Response of the climate system to aerosol direct and indirect forcing: Role of cloud feedbacks, J. Geophys. Res.Atmos., 110(13), D24206, doi:10.1029/2005jd006299, 2005.
Law, K. S. and Stohl, A.: Arctic air pollution: Origins and impacts, Science, 315, 1537-1540, 2007.

Lin, C. J., Cheng, M. D., and Schroeder, W. H.: Transport patterns and potential sources of total gaseous mercury measured in Canadian high Arctic in 1995, Atmos. Environ., 35, 1141-1154, 2001.

Quinn, P. K., Shaw, G., Andrews, E., Dutton, E. G., Ruoho-Airola, T., and Gong, S. L.: Arctic haze: current trends and knowledge gaps, Tellus B, 59, 99-114, 2007.

Ramanathan, V. and Carmichael, G.: Global and regional climate changes due to black carbon, Nat. Geosci., 1, 221-227, doi:10.1038/ngeo156, 2008.

Serreze, M. C. and Barry, R. G.: The Arctic Climate System, Cambridge Atmospheric and Space Science Series, edited by: Dessler, A. J., Houghton, J. T., and Rycroft, M. J., Cambridge University Press, New York, 412 pp., 2005.

Sharma, S., Lavoue, D., Cachier, H., Barrie, L. A., and Gong, S. L.: Long-term trends of the black carbon concentrations in the Canadian Arctic, J. Geophys. Res.-Atmos., 109(10), D15203, doi:10.1029/2003JD004331, 2004.

Sharma, S., Andrews, E., Barrie, L. A., Ogren, J. A., and Lavoue, D.: Variations and sources of the equivalent black carbon in the high Arctic revealed by long-term observations at Alert and Barrow: 1989-2003, J. Geophys. Res.-Atmos., 111(15), D14208, doi:10.1029/2005jd006581, 2006.

Sharma, S., Ishizawa, M., Chan, D., Lavoué, D., Leaitch, R., Worthy, D., Andrews, E., Eleftheriadis, K., Mefford, T., and Maksyutov, S.: Synoptic Transport of Anthropogenic BC to the Arctic, NOAA annual conference, Boulder, CO, 2009,

Shaw, G. E.: The arctic haze phenomenon, B. Am. Meteorol. Soc., 76, 2403-2413, 1995.

Shindell, D. T., Chin, M., Dentener, F., Doherty, R. M., Faluvegi, G., Fiore, A. M., Hess, P., Koch, D. M., MacKenzie, I. A., Sanderson, M. G., Schultz, M. G., Schulz, M., Stevenson, D. S., Teich, H., Textor, C., Wild, O., Bergmann, D. J., Bey, I., Bian, H., Cuvelier, C., Duncan, B. N., Folberth, G., Horowitz, L. W., Jonson, J., Kaminski, J. W., Marmer, E., Park, R., Pringle, K. J., Schroeder, S., Szopa, S., Takemura, T., Zeng, G., Keating, T. J., and Zuber, A.: A multi-model assessment of pollution transport to the Arctic, Atmos. Chem. Phys., 8, 5353-5372, doi:10.5194/acp-8-5353-2008, 2008.

Stohl, A.: Characteristics of atmospheric transport into the Arctic troposphere, J. Geophys. Res.-Atmos., 111(17), D11306, doi:10.1029/2005jd006888, 2006.

United Nations: The United Nations energy statistics database (2005), United Nations Statistics Division, New York, 5, 2007.

Warneke, C., Froyd, K. D., Brioude, J., Bahreini, R., Brock, C. A., Cozic, J., de Gouw, J. A., Fahey, D. W., Ferrare, R., Holloway, J. S., Middlebrook, A. M., Miller, L., Montzka, S., Schwarz, J. P., Sodemann, H., Spackman, J. R., and Stohl, A.: An important contribution to springtime Arctic aerosol from biomass burning in Russia, Geophys. Res. Lett., 37(5), L01801, doi:10.1029/2009g1041816, 2010.

Worthy, D. E. J., Trivett, N. B. A., Hopper, J. F., Bottenheim, J. W., and Levin, I.: Analysis of Long-Range Transport Events at Alert, Northwest-Territories, During the Polar Sunrise Experiment, J. Geophys. Res.-Atmos., 99, 25329-25344, 1994. 